\title{
Verbessert digitales Nudging die Sicherheit in der Informationstechnik?
}

Im September 2019 kamen Verbraucherforscherinnen und -forscher im Wissenschaftszentrum Bonn zu einem Forum des Netzwerks Verbraucherforschung zusammen. Ziel dieses Forums war es, gemeinsam mit dem Bundesamt für Sicherheit in der Informationstechnik (BSI) verschiedenen Aspekten der Datensicherheit und der Privatheit nachzugehen. So wurde debattiert, inwieweit Anbieter digitales Nudging einsetzen, um Entscheidungen der Nutzer in Hinblick auf Datensicherheit und „Privacy“ zu beeinflussen. Aber auch die Politik kann digitales Nudging anwenden, um Verbrauchern diese Problematik bewusst zu machen. In diesem Zeitgespräch dokumentieren wir die Beiträge der Vortragenden.

Digital Nudging - Implikationen für die Verbraucherforschung und die Verbraucherpolitik

Peter Kenning, Heinrich-Heine-Universität Düsseldorf.

Nudging hell und dunkel: Regeln für digitales Nudging

Lucia A. Reisch, Zeppelin Universität Friedrichshafen; Copenhagen Business School.

Verhaltenswissenschaftlich informierte Politik für mehr Cybersicherheit

Kathrin Loer, FernUniversität in Hagen.

Digitales Nudging kann Nutzer online schützen

Thomas Hess, Ludwig-Maximilians-Universität München.

Charlotte Schöning, Ludwig-Maximilians-Universität München.

Behavioral Economics und Verbraucherschutz sowie Sicherheitsrecht in der IT-Welt Gerald Spindler, Georg-August-Universität Göttingen.

Grundsätze ordnungsmäßiger Verbraucherinformationssysteme

Reinhard Schütte, Universität Duisburg-Essen.

Digitale Verhaltenspolitik - Herausforderungen und Umsetzungshürden

Holger Straßheim, Universität Bielefeld.

Title: Does Digital Nudging Improve Security in Information Technology?

Abstract:In September 2019, consumer researchers met at the Wissenschaftszentrum Bonn for a forum of the Consumer Research Network. The aim of this forum was to investigate, together with the Federal Office for Information Security, the various aspects of data security and privacy. Participants debated the extent to which providers employ digital nudging to influence user decisions with regard to data security and privacy. On the other hand, politicians can also use digital nudging to make consumers aware of these issues. In this Zeitgespräch, we document the contributions of the speakers.

JEL Classification: D18, K24, P14 